\title{
Markers Usefulness in the Melanic Metastatic Cellular Epitops Identification in the Sentinel Lymph Node
}

\author{
LAURA ENDRES ${ }^{1}$, DELIA MIRELA TIT ${ }^{1}$, SIMONA BUNGAU ${ }^{1}$, GABRIELA CIOCA ${ }^{2 *}$, MOHAMED ABDEL DAIM ${ }^{3,4}$, CAMELIA BUHAS ${ }^{1}$, \\ OVIDIU POP1*, CRISTIAN SAVA ${ }^{1}$ \\ ${ }^{1}$ University of Oradea, Faculty of Medicine and Pharmacy, 29 N. Jiga Str., 410028, Oradea, Romania \\ 'Lucian Blaga University of Sibiu, Faculty of Medicine, 10 Victoriei Blvd., 550024, Sibiu, Romania \\ ${ }^{3}$ Suez Canal University, Faculty of Veterinary Medicine, Ismailia 41522, Egypt \\ ${ }^{4}$ Yokohama City University, Department of Ophthalmology and Micro-technology, Yokohama, Japan
}

Cutaneous melanoma is the most severe skin neoplasia with an increased incidence in the recent decades, particularly due to the intense exposure to sunlight. Our study analyzed the characteristics of malignant melanoma and the role of sentinel node biopsy in the diagnosis and prognosis of the patients with cutaneous melanoma by identifying the regional metastasis. The small or large clusters of circulating cancer cells are expressing epitops identified by some chemical reaction. These reagents are usually monoclonal antibodies with high sensitivity and specificity which are matching with the right receptor from the melanoma cells. The result is an antibody-antigen complex high-light in the microscopic examination by 3,3-diaminobenzidine $(D A B)$. The study was conducted on a sample of 151 patients diagnosed with melanoma in different developmental stages: 62 had Breslow index between 1-4 mm, 71 patients had Breslow index A $4 \mathrm{~mm}$ and 18 patients had Breslow index $<1 \mathrm{~mm} .45$ patients (out of 62) with Breslow index between 1-4 $\mathrm{mm}$ had SLN positive. The mortality rate was $5 \%$ in the case of the patients with SLN positive. Comparing the rate of mortality by considering the Breslow index, $65 \%$ of the patients with Breslow index A $4 \mathrm{~mm}$ died. The correct identification of the patients with negative sentinel node or positive sentinel node improves staging and can facilitate the subsequent therapeutic decision, which is useful for early identification of the micro metastases and of the patients who require regional complete lymph node dissection.

Keywords: malignant melanoma, sentinel node, prognostic.

The melanocytes are cells of neuroectodermal origin that synthesize the melanin pigment [1]. The consequence of the malignant transformation of this kind of cells is cutaneous melanoma (MMC), which is well known from the literature to be the most severe type of skin neoplasia. The incidence of MMC increased in the last decades, especially because of a more intense exposure to the ultraviolet $B$ radiation (UVR-B), particularly among the white population [2,3]. MMC is also considered a form of aggressive skin cancer $[4,5]$. Although some therapeutic advances were made, the survival rate for people with MMS for a period of 5 years is less than $5 \%$ and median survival ranges from 6-8 months. The prognosis remains unfavorable, metastatic melanoma remaining incurable $[6,7]$.

According to the definition of A. Breslow, published in 1969, the thickness of the tumor is measured from the top of the granular layer to the deepest level of invasion of the tumor cells that. It is grouped as follows: Breslow I - tumor thickness < $0.76 \mathrm{~mm}$; Breslow II - tumor thickness 0.76$1.49 \mathrm{~mm}$; Breslow III - tumor thickness 1.50-2.49 mm; Breslow IV - tumor thickness 2.50-2.99 mm; Breslow V tumor thickness $>4.00 \mathrm{~mm}$ [8].

Levels of invasion were first described in 1967 by W. Clark and are an important tool for evaluation, being substantial for the appreciation of the treatment strategy. They are included in the international classification which was updated in 2002 by addressing also the primary tumor: level I - melanoma in situ - the cure rate is $100 \%$ at this stage; level II - dermal papilla melanocytes extended; level III - invading the papillary dermis; level IV - invading the reticular dermis; level $\mathrm{V}$ - hypodermis invasion [9]. The two classifications are tightly correlated. In some clinics,
Clark index is considered, while in other the Breslow index [10]. According with the NCCN Guidelines version 1.2017 the Clark index should be used for non-ulcerated melanoma $<1 \mathrm{~mm}$ thick when the mitotic rate is not done [11]. By modifying the melanoma staging guide (in 2002), the American Joint Committee on Cancer System (AJCC) connects the stage and the prognosis [10,12]. In 2009, AJCC defines the prognosis of the metastatic lymph nodes $(\mathrm{N})$, distinguishing between micro metastases diagnosed after sentinel node biopsy (SLN) - and macro metastases $[13,14]$. AJCC 8th-edition (2018) states that satellite(s) or in transit metastasis are included in TNM Clinical Classification [15].

The most important prognostic factor for patients with early stages of melanoma and for $20 \%$ of the intermediate thickness melanoma cases is the metastasis into regional lymph nodes [16,17]. Also, the identification of the patients for which complete regional lymph node dissection benefits exceed risks by surgical mortality is very important. Sentinel node biopsy should be used in treatment plans (complete lymph node dissection and adjuvant therapy) as well as in clinical treatments [18]. In nodal intervention in patients without nodal metastases, critical prognostic information is obtained; this intervention has no therapeutic benefits [19]. Most of the pathologists agree that for the pure desmoplastic melanoma is not recommended the SLN $[20,21]$.

SLN status is considered an important prognostic factor in patients with Breslow thickness $>1 \mathrm{~mm}$ in clinicalnegative MMC [4]. For patients recently diagnosed with melanoma, in the case of cutaneous melanoma with intermediate thickness, having a thickness between 1-4 
$\mathrm{mm}$ Breslow, the biopsy of the sentinel node is considered appropriate. In the case of melanoma with high thickness ( $4 \mathrm{~mm}$ Breslow index), the SLN biopsy can be recommended for staging, limitation and local control; however, this investigation is questionable because the prognosis is poor and the risk of haematogenic dissemination is high in this subset of patients [22]. In the case of melanoma of smaller thickness (Breslow $<1 \mathrm{~mm}$ ) there is an insufficient evidence to support the biopsy routine, although itcan be taken in consideration in patients at high risk. Complete lymph node dissection is recommended in all patients with positive SLN [21-23]. In the case of melanoma, patients with intermediate thickness melanomas (with clinically occult nodal metastases), an early intervention significantly lowers the risk of distant metastases, node recurrence, and MMC deaths [19].

The purpose of this study was to analyze the role of sentinel node biopsy in the diagnosis and prognosis of patients with cutaneous melanoma, by identifying the regional metastasis.

\section{Experimental part}

Materials and methods

Study design

The study was performed over a period of 4 years (from 2010 to 2013) on a group of 151 patients that were diagnosed with melanoma in different stages of evolution in three different hospitals from Romania: Surgical Clinics of the Clinical Emergency County Hospital Oradea and the Pelican Hospital from Oradea, in collaboration with the Cancer Institute Prof. Dr. Ion Chiricuta, Cluj - Napoca. In this study, patients diagnosed with cutaneous melanoma with intermediate Breslow (1-4 mm) were included, in which case sentinel ganglion biopsy was recommended irrespective of the anatomical area. Patients with Breslow $>4 \mathrm{~mm}$ (although few studies focusing on these patients, sentinel ganglion biopsy may be recommended for staging and regional disease control) and those with Breslow $<1$ $\mathrm{mm}$ (there is not enough evidence to support the routine sentinel ganglion biopsy and can be considered in highrisk, depending on the risk-versus-benefit ratio) were excluded from the study.

The study was conducted in accordance with the W MA Declaration of Ethical Helsinki- Medical Research Involving Human Principles for Subjects, approved by the Ethic Committee of the Faculty of Medicine and Pharmacy from the University of Oradea and by the Commission for internal approval of the research-development of the hospitals mentioned above. The risks and the complications of the surgical excision of the tumor were explained to all the patients; after that, they have completed and signed an informed consent form [24].

Data were prospectively collected, stored and processed using Microsoft $\circledast$ Excel $\circledast 2010$ (Microsoft Corporation, USA), representing the database of statistical study, where we tracked: the demographics data (gender, age, origin), the location of the melanoma, the surgical excision of the primary tumor, the sentinel node biopsy result (positive or negative SLN), the local conducted complete lymph node dissection in patients with positive SLN, the complications post-complete lymph node dissection, the survival and the mortality rate [24].

\section{Clinical investigations}

The SLN technique is based on lymphoscintigraphy, using Technetium - $99 \mathrm{~m}$ as a radioactive tracer. After the identification of the regional lymph node, it was removed by using surgical procedure and analyzed by a skilled pathologist. The tissue was embedded in paraffin, cut and stained by $H \& E$ and immunohistochemistry. For each case our protocol stated that 4 slides are to be made; 2 for $H \& E$ and 2 for HMB-45 and S100.

The sections prepared from formalin-fixed paraffin embedded tissue of $4 \mu \mathrm{m}$ thickness were analyzed immunohistochemically using an automated immunostainer (Bechmark GX, Ventana Medical Systems Inc., Tucson, AZ, USA). Slides were deparaffinized using EZprep solution (Ventana Medical Systems, Inc.) at $900^{\circ} \mathrm{C}$, and all reagents and incubation times were chosen as directed on antibody package inserts. Slides were developed using the DAB (3,3'-diaminobenzidine) detection kit (Ventana Medical Systems, Inc.) and counterstained with Hematoxylin. We marked the section with anti-melanosome (HMB45 clone) a mouse monoclonal antibody, and anti-S100 (4C4.9 clone) a mouse monoclonal antibody, markers provided by Ventana Medical Systems, Inc. The negative control was performed by same protocol with antibodies omission [25].

\section{Statistical analysis}

For the statistical analysis there were used the health statistics program MedCalc ${ }^{\circledR}$ version 12.2.1.0 (MedCalc $®$ Software, Mariakerke, Belgium). The results of the statistical tests are represented by the probability of the null hypothesis $(p)$, its value below 0.05 proving a statistically significant difference between the studied groups. The categorical variables are described by their absolute values and the percentages in brackets are studied using the following tests: chi-square, Fisher's exact test and One Sample T-test. In order to study the implication of these variables as risk factors, the risk was determined relative to a confidence interval of $95 \%$ (IC), statistically $Z$, and $p$ value. If $p$ is less than 0.05 , it can be concluded that the relative risk is significantly different from 1 and that there is a higher risk in one group than another.

\section{Results and discussions}

The demographic study in melanoma patients included in the study showed no statistically significant differences regarding the gender and area of origin. Almost $55 \%$ of patients were male (54.97\%), male / female ratio was 1.2:1 and more than $55 \%$ of patients from urban areas $(55.63 \%)$, urban / rural being 1.3:1. Instead statistically significant differences were obtained for different age groups. The patients were divided into six age groups: $\leq 30$ years, 3140 years, $41-50$ years, 51-60 years, $61-70$ years, and $>70$ years. The study demonstrates that cutaneous melanoma is present at any age, but with a statistically significant preponderance between $51-70$ years $(55.70 \%$ ) ( $p$ $<0.0001$ ). The average age of the patients admitted in our study was 58.33 years (table 1 ).

The cutaneous melanoma was diagnosed after surgical excision of the tumor formation and of the histopathological exam. Ithad different locations in various parts of the body: lip, ear and external auditory canal, face, eyelid, primary hairy skull and neck, upper limbs, lower limbs, trunk, lesions below the skin; it was located in $52.31 \%$ of the cases at the level of the trunk, lower limbs and lips. Considering 151 patients, 62 had Breslow index between 1-4 $\mathrm{mm}, 71$ patients had Breslow index $>4 \mathrm{~mm}$ and 18 patients had Breslow index $<1 \mathrm{~mm}$ (table 2).

The largest thickness was that of patients with Breslow index $>4 \mathrm{~mm}$. This is explained by the fact that most patients are going to the doctor in an evolutionary stage of the disease, when there already metastasized melanoma is installed. The biopsy procedure of the sentinel node (SLN), 


\begin{tabular}{|c|c|c|c|c|}
\hline \multicolumn{2}{|c|}{ Characteristics } & \multirow{2}{*}{$\begin{array}{c}\text { No. } \\
83\end{array}$} & \multirow{2}{*}{$\frac{\%}{54.97}$} & $p$ \\
\hline Gender & Male & & & \multirow{7}{*}{ - } \\
\hline & Female & 68 & 45.03 & \\
\hline \multirow[t]{2}{*}{ Provenience area } & Urban & 84 & 55.63 & \\
\hline & Rural & 67 & 44.37 & \\
\hline \multirow{6}{*}{$\begin{array}{c}\text { Age groups } \\
\text { (years) }\end{array}$} & $\leq 30$ & 6 & 3.97 & \\
\hline & $31-40$ & 7 & 4.64 & \\
\hline & $41-50$ & 23 & 15.6 & \\
\hline & $51-60$ & 53 & 35.17 & \multirow[t]{3}{*}{$p<0.0001^{*}$} \\
\hline & $61-70$ & 46 & 30.53 & \\
\hline & $>70$ & 15 & 10.08 & \\
\hline
\end{tabular}

Table 1

DEMOGRAPHIC CHARACTERISTICS OF THE PATIENTS

* Chi-square test

\begin{tabular}{|c|c|c|c|c|}
\hline \multicolumn{2}{|l|}{ Characteristics } & No. & $\%$ & $p$ \\
\hline \multirow{10}{*}{$\begin{array}{l}\text { Site of primary } \\
\text { tumor }\end{array}$} & Lip & 28 & 18.54 & \multirow[t]{10}{*}{$p=0.0005^{88}$} \\
\hline & Eyelid & 4 & 2.65 & \\
\hline & Ear and the ear canal & 10 & 6.62 & \\
\hline & Face & 19 & 12.58 & \\
\hline & $\begin{array}{l}\text { Hairy skin of the skull and } \\
\text { neck }\end{array}$ & 9 & 5.96 & \\
\hline & Trunk & 28 & 18.54 & \\
\hline & Upper limb & 12 & 7.95 & \\
\hline & Lower limb & 23 & 15.23 & \\
\hline & $\begin{array}{c}\text { Surpassing melanoma skin } \\
\text { lesions }\end{array}$ & 4 & 2.65 & \\
\hline & Skin, without specifying & 14 & 9.27 & \\
\hline \multirow[t]{3}{*}{ Breslow thickness } & Breslow 1-4 mm & 62 & 41.05 & \multirow[t]{3}{*}{$\mathrm{p}=0.9998^{\circ}$} \\
\hline & Breslow $>4 \mathrm{~mm}$ & 71 & 47.01 & \\
\hline & Breslow $<1 \mathrm{~mm}$ & 18 & 11.92 & \\
\hline
\end{tabular}

Table 2

CLINICAL AND HISTOPATHOLOGICAL FEATURES

${ }^{*}$ One sample T-test, * Chi-square test

was followed in Oncology Institute Prof. Dr. Ion Chiricuta from Cluj -Napoca. Results are presented in table 3.

Table 3

SENTINEL NODE BIOPSY RESULTS

\begin{tabular}{|c|c|c|c|}
\hline Results & No. & $\%$ & $p$ \\
\hline SLN positive & 45 & 72.58 & \multirow{2}{*}{$\mathrm{p}=1.000^{*}$} \\
\cline { 1 - 3 } SLN negative & 17 & 27.42 & \\
\hline
\end{tabular}

${ }^{*}$ Fisher's exact test

The metastatic melanoma cells in subcapsular sinus were found as small cluster or large cluster. The melanoma cells destroyed most of the normal lymphoid structure, in some cases in which the lymph node invasion was significant. The most difficult cases are that cases named amelanotic melanoma. The presence of melanophages can rise the difficulty of the melanoma diagnosis. The acilary tools (immunohistochemistry) may help in the accuracy of the final diagnosis. We used the mostcommon antibodies for diagnosis of melanoma: HMB-45 and S100. The markers are negative for melanophages. In our study group there was a rare case of spindel cell melanoma. In the next image can be seen a spindle cell proliferation replacing most of the lymph node structure (fig. 1). The

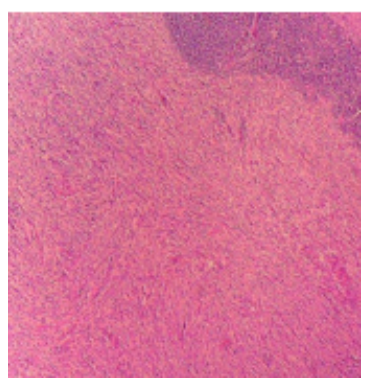

Fig. 1. Spindel cell melanoma metastasis in the lymph node $\mathrm{HE}$ $100 \mathrm{X}$

normal histological structure is preserved in the upper right corner.

The high magnification microscopic examination point out scatered brown-yellowish pigment in the spindel cell (fig. 2).

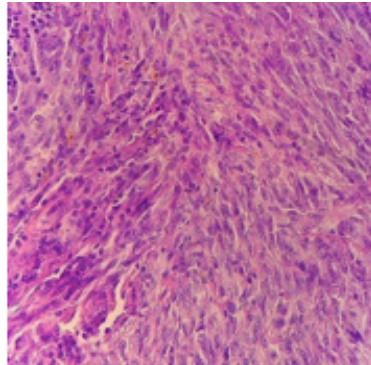

Fig. 2. Brown-yellow pigmentation HE 200X 
In the HE tissue examination can be diagnosed the morpholgical melanoma types and sometime can provides information about metastasis too. The presence of the melanin inside or outside the melanoma cells can guide the pathologist. The immunohistochemistry reaction becomes an important tool in the doubtful cases or in the micrometastasis. Figure 3 shows the lymphoide follicle betw een a wide malignant melanoma mets (S100-brown color). The analyze of the subcapsular sinus is negative for immunohistochemistry markers.

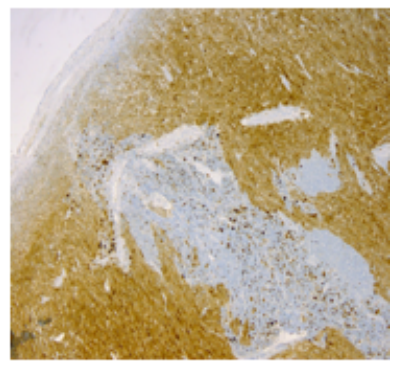

Fig. 3. S100 positive expresion in the lymph node. The brown-tan melanoma cell distroy most of the normal architecture

All the positive cases from our study (45) were strong positive for S100 and HMB45. There ar many marker to mark and identify melanocitic cells as S100, HMB45, SOX10, MART1, MiTF, but we chosed for our study two themes (S100, HMB45). Because MART1, a common marker, interfears with macrophages, we label the melanoma cells with HMB45 (fig. 4).

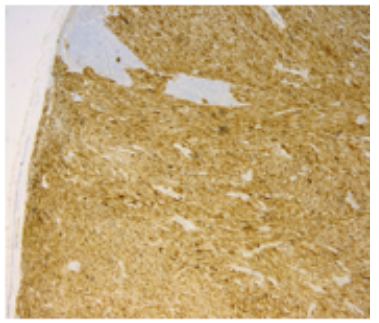

Fig. 4. HMB45 strong positive expression inside the lymphnode

At 45 patients with positive SLN was performed the regional complete lymph node dissection. With no statistically significant difference, the postoperative morbidity causes were: the presence of the local lymphedema, the seroma, the infection, the postoperative local wound and the wound dehiscence (table 4).

\section{Table 4}

COMPLICATIONS POST-LYMPHADENECTOMY

\begin{tabular}{|c|c|c|c|}
\hline Complications & No. & $\%$ & $p$ \\
\hline Local lymphedema & 8 & 18 & \multirow{2}{*}{$\mathrm{p}=0.9988^{*}$} \\
\hline Seroma & 2 & 4 & \\
\hline Local wound infection & 3 & 7 & \\
\hline Descent wound & 1 & 2 & \\
\hline
\end{tabular}

* Chi-square test

The positive SLN 45 patients followed an adjuvant treatment with Interferon, with a positive evolution. 17 patients with negative SLN were monitored at every 3 months. The death rates evaluated according to Breslow index, indicate that $65 \%$ of patients with Breslow index $>4 \mathrm{~mm}$ died. In patients with positive SLN the mortality rate was of $5 \%$ (table 5 ).

Analyzing the evolution of the patients with cutaneous melanoma from the statistical point of view, the great majority of patients had an amelioration of the disease, in a proportion of $55.62 \%$. Of total, we recorded 14 cases cured batch $(9.27 \%)$ : one case of melanoma of the face and one case of the hairy skin of the skull and neck, 5 cases of malignant melanoma of the trunk and 7 cases at the level of the lower limbs. 3 patients were stationary
Table 5

THE SURVIVAL AND THE MORTALITY RATE BASED ON THE BRESLOW INDEX

\begin{tabular}{|l|c|c|c|c|c|}
\hline \multirow{2}{*}{ Breslow thickness } & \multicolumn{2}{|c|}{ Survived } & \multicolumn{2}{|c|}{ Deceased } & \multirow{2}{*}{} \\
\cline { 2 - 5 } & No. & $\%$ & No. & $\%$ & \\
\hline Breslow $<1 \mathrm{~mm}$ & 17 & 95 & 1 & 4 & $\mathrm{p}=0.0921^{*}$ \\
\hline Breslow $1-4 \mathrm{~mm}$ & 59 & 95 & 3 & 5 & $\mathrm{RR}=0.8710$ \\
\hline Breslow $>4 \mathrm{~mm}$ & 25 & 35 & 46 & 65 & $\begin{array}{c}\mathrm{p}<0.0001^{*} \\
\mathrm{RR}=0.07468\end{array}$ \\
\hline
\end{tabular}

* Chi-square test, RR - Relative risk

Table 6

EVOLUTION OF THE DISEASE

\begin{tabular}{|c|c|c|c|}
\hline Evolution & No. & $\%$ & $p$ \\
\hline Cured & 14 & 9.27 & \multirow{4}{*}{$\mathrm{p}<0.0001^{* *}$} \\
\hline Improved & 84 & 55.62 & \\
\hline Stationary & 3 & 1.98 & \\
\hline Death & 50 & 33.11 & \\
\hline
\end{tabular}

because clinically and surgically were overwhelmed. The total mortality was $33.11 \%$ (table 6).

The correct identification of the patients with negative SLN (stage I or II) or positive sentinel nodes (stage III) improve the staging and facilitates the regional control of the disease and the therapeutic decision for adjuvant therapy $[18,26]$.

In the case of submicroscopic melanoma metastasis in the SLN can be used another method, reversetranscription PCR, to identify the cancer cells. Blaheta et al. presented a paper where, from the 101 negative SLN diagnosed by immunohistochemistry, 36 cases (using reverse-transcription $P C R$ ) were converted to the positive SLN [27]. According with this paper and with other researches, the PCR approach in the malignant melanoma SLN seems to be a more sensitive method.

In many studies the authors tried to find out any correlation between the false-negative SLN diagnosed by immunohistochemistry (reconvert to true-positive by RTPCR) and the clinical course. If are compared the falsenegative SLN with true-positive SLN, from specific survival point of view the studies could not find any relevant [28]. By changing the staging melanoma guide in 2002, the AJCC system links the stage and the prognosis [11,13]. In 2009, A) CC metastatic lymph define prognosis (N), distinguishing between micro metastases (diagnosed after biopsy SLN) and macro metastases [12,29]. Local macro metastases is detected by clinical examination (not on size criteria) and confirmed by histopathology, while a micro metastases is invisible clinical, and is diagnosed by the histopathology specialist using microscopic examination of the lymph nodes, with or without immunohistochemistry. Should be mention that the SLN technique can be perform byinjection of blue dye in the primary melanoma site. Some of the centers prefer the last one, but other like both SLN techniques.

Another issue took in account by us in our study was the chance to find benign melanocytic cells inside the SLN. According Carson et al, a higher number of SLN removed for malignant melanoma contain benign melanocytic cells. For this reason, it is important to have a strait diagnosis of metastasis because the prognosis and the therapeutic plan is in the close relationship [30]. The rate of survival in a 
Breslow index $<1 \mathrm{~mm}$ is between $95-100 \%$, in a Breslow index $1-2 \mathrm{~mm}$ is $80-90 \%$, in a Breslow index from 2.1 to 4 $\mathrm{mm}$ is $60-75 \%$, and in a Breslow index $>4 \mathrm{~mm}$ is $50 \%$. Therefore, the patients with thick melanoma had a higher mortality risk than the patients with intermediary melanoma. Including SLN biopsy in the management of melanoma cases improved the survival rate and therefore offers a better prognosis. These data are consistent with those found in the literature [20]. For the thick melanoma one of the main benefits of SLN biopsy is the better regional control, which is a particularly important issue for more than $30 \%$ of the patients with involved lymph nodes [29].

Generally, SLN routinely biopsy in patients with thin melanoma was not supported because the risk of getting involved nodules is 5.1\% [24]. The reports show thatSLN is positive in up to $20 \%$ of the patients with thin melanoma (especially those that are from 0.75 to $0.99 \mathrm{~mm}$ thick with ulceration / mutagenicity $\geq 1 / \mathrm{mm}$ ) [30]. The patients with positive SLN requires local complete lymph node dissection (CLND). It aims to improve the survival rate, to maximize the regional control, and to decrease the postoperative mortality. It has been demonstrated that patients with regional metastases excised in the first stage after the diagnosis had a greater survival rate compared to patients in case of which this procedure was made later [31].

\section{Conclusions}

The correct identification of the patients with negative sentinel node or positive sentinel node and also satellite or in transit metastasis identification improves staging and can facilitate the subsequent therapeutic decision, which is useful for early identification of the micro metastases and of the patients who require regional complete lymph node dissection. The marker of tumour aggressiveness and an important prognostic factor in patients with melanoma is the detection of lymph node micro metastases through the sentinel node biopsy. The information provided by the SNB allows a better diagnostic accuracy and prognosis and determines the therapeutic approach for these patients. The immunohistochemistry technique used in addition to $H \& E$ for detecting melanoma metastasis in the lymph nodes is a feasible approach to routinely SLN examination. As a feature of the study, most patients are going to the doctor in an evolutionary stage of the disease, when there already exist a metastasized melanoma.

\section{References}

1.CICHOREK, M., WACHULSKA, M., STASIEWICZ, A., TYMINSKA, A. Postepy. Dermatol. Alergol., 30, no. 1, 2013, p. 30.

2.NARAYANAN, D.L., SALAD, R.N., FOX, J.L., Int. J. Dermatol., 49, no. 9, 2010, p. 978.

3.FUNASAKA, Y., ABDEL-DAIM, M., KAWANA, S., NISHIGORI, C., Exp. Dermatol., 21, no. 1, 2012, p. 31.

4.CHEN, J, XU, Y., ZHOU, Y., WANG, Y., ZHU, H., SH, Y., Oncotarget., 7, 2016, p. 45671.

5.SIEGEL, R.L., MILLER, K.D., JEMAL A., CA Cancer J. Clin., 66, 2016, p. 7.

6.OHTANI, Y., HARADA, T., FUNASAK,A Y., NAKAO, K., TAKAHARA, C., ABDEL-DAIM, M., SAKAI, N., SAITO, N., NISHIGORI, C., AIBA, A., Oncogene, 27, 2008, p. 7162.

7.ABDEL-DAIM, M., FUNASAKA, Y., KOMOTO, M., NAKAGAWA, Y., YANAGITA, E., NISHIGORI, C., J. Dermatol., 37, 2010, p. 635.

8.***, Breslow A. Ann. Surg., 1970.
9.WEEDON, D., Skin pathology, 2nd ed., Publisher: ChurchillLivingstone, Sydney, Australia, 2002.

10.BALCH, C.M., BUZAID, A.C., SOONG, S.J., ATKINS, M.B., CASCINELLI, N., COIT, D.G., FLEMING, I.D., GERSHENWALD, J.E., HOUGHTON, A. JR., KIRKWOOD, J.M., MCMASTERS, K.M., MIHM, M.F., MORTON, D.L., REINTGEN, D.S., ROSS, M.I., SOBER, A., THOMPSON, J.A., THOMPSON, J.F., J. Clin. Oncol., 19, 2001, p. 3635.

11. ${ }^{* * *}$ NCCN Clinical Practice Guidelines. Melanoma, version 1. 2016. Available online https://www.nccn.org/professionals/physician_gls/ default.aspx (16 March 2017)

12.BALCH, C.M., SOONG ,S.J ., GERSHENWALD, J.E., THOMPSON, J.F., REINTGEN, D.S., CASCINELLI, N., URIST, M., MCMASTERS, K.M., J. Clin. Oncol., 19, 2001, p. 3622.

13.GERSHENWALD, J.E., MANSFIELD, P.F., LEE, J.E., ROSS, M.I., Ann. Surg. Oncol., 7, 2000, p. 160.

14.FERRONE, C.R., PANAGEAS, K.S., BUSAM, K., COIT, G.D., Ann. Surg. Oncol., 9, 2002, p. 637.

15.*** Cancer Staging, www.ujcc.org (26 May 2018)

16.BALCH, C.M., GERSHENWALD, J.E., SOONG, S.J ., THOMPSON, J.F., ATKINS, M.B., BYRD, D.R., BUZAID, A.C., COCHRAN, A.J ., COIT, D.G., DING, S., EGGERMONT, A.M., FLAHERTY, K.T., GIMOTTY, P.A., KIRKWOOD, J.M., MCMASTERS, K.M., MIHM, M.C. JR, MORTON, D.L., ROSS, M.I., SOBER, A.J., SONDAK, V.K., J. Clin. Oncol., 27, 2009, p. 6199.

17.BALCH, C.M., GERSHENWALD, J.E., SOONG, S.J ., THOMPSON, J .F., DING, S., BYRD, D.R., et al., J. Clin. Oncol., 28, 2010, p. 2452.

18.BALCH, C.M., MORTON, D.L., GERSHENWALD, J.E., MCMASTERS, K.M., NIEWEG, O.E., POWELL, B., ROSS, M.I., SONDAK, V.K., THOMPSON, J.F., J. Am. Acad. Dermatol., 60, 2009, p. 872.

19.MORTON, D.L., THOMPSON, J.F., COCHRAN, A.J., MOZZILLO, N., NIEWEG, O.E., ROSES, D.F., et al., Engl. J. Med., 370, no.7, 2014, p. 599.

20.PAW LIK, T.M., ROSS, M.I., PRIETO, V.G., BALLO, M.T., JOHNSON, M.M., MANSFIELD, P.F., LEE, J.E., CORMIER, J.N., GERSHENWALD, J.E., Cancer 106, no. 4, 2006, p. 900.

21.BROER, P.N., WALKER, M.E., GOLDBERG, C., BUONOCORE, S., BRADDOCK, D.T., LAZOVA, R., NARAYAN, D., ARIYAN, S. Eur. J. Surg. Oncol., 39, no. 7, 2013, p. 681.

22.LEILABADI, S.N., CHEN, A., TSAI, S., SOUNDARARAJAN, V., SILBERMAN, H., WONG, A.K., Healthcare (Basel), 22, no. 2, 2014, p. 234.

23.SAMSANAVICIUS, D., KAIKARIS, V., NORVYDAS, S-J., LIUBAUSKAS, R., VALIUKEVICIENE, S., MAKSTIENE, J., MASLAUSKAS, K., RIMDEIKA, R., Medicina, 52, 2016, p. 276.

24.ENDRES, L., Clinical and therapeutic news in melanoma, PhD Thesis. University of Oradea, Oradea, 2014.

25.*** Roche tissue diagnostics, Search By Disease State, http:// w w w. ventana.com/product/disease? Disease $\% 5$ Bid\%5D\%5B\%5D=4\&yt0=Submit (17 May 2017).

26.ENDRES, L., UIVAROSAN, D., TIT, D.M., POP, O., BUNGAU, S., BUHAS, C., Iran. J. Pub. Health, 47, 2018, p. 606.

27.SUGIE, T., KASSIM, K.A., TAKEUCHI, M., et al., Cancers, 2, 2010, p. 713.

28.MANCA, G., ROMANINI, A., RUBELLO, D., MAZZARRI, S., BONI, G., CHIACCHIO, S., et al., Q. J. Nucl. Med. Mol. Imaging., 58, no. 2, 2014, p. 105.

29.MINUTILLI, E., GIANNARELLI, D., ANZA, M., GARINEI, R., PERRI, P., BOTTI, C., et al., J. Exp. Clin. Cancer Res., 26, no. 6, 2007, p. 71.

30.CARSON, K.F., WEN, D.R., LI, P.X., LANA, A.M., BAILLY, C., MORTON, D.L., COCHRAN, A.J., Am. J. Surg. Pathol., 20, no. 7, 1996, p. 834.

31.GAJ DOS, C., GRIFFITH, K.A., WONG, S.L., JOHNSON, T.M., CHANG, A.E., CIMMINO, V.M., et al., Cancer , 115, 2009, p. 5752.

Manuscript received: 18.07 .2018 